\title{
STUDY ON SPATIAL CHARACTERISTICS ON RUMAH PANGGONG IN SIJUK DISTRICT, BANGKA BELITUNG
}

\author{
Dimas Wihardyanto ${ }^{1 *}$, Sherlia $^{2}$ \\ ${ }^{1}$ Department of Architecture and Planning, Gadjah Mada University, Jl. Grafika No.2 Kampus UGM, \\ Yogyakarta 55281, INDONESIA \\ ${ }^{2}$ Department of Architectural Engineering, University of Technology Yogyakarta, Jl. Glagahsari No. 63 \\ Kampus 2 UTY, Warungboto, Umbulharjo, Yogyakarta 55164, INDONESIA \\ "Corresponding author; Email: wihardyanto@gmail.com
}

\begin{abstract}
Rumah Panggong is a form of local architecture in Belitung Island, where there are not many architectural studies focusing on it. This study focused on the spatial aspect, because space is the firstly generated architectural design idea to facilitate activities or society culture before later developed into the form, structure, materials, and so forth. The approach used was qualitative descriptive with emphasis on data collection method using field observations, as well as data analysis method using a coding system, which included open coding, axial coding phase and selective coding phase. Through this research, it was found that Rumah Panggong is formed into 3 parts, namely mother room, suyok or porch, and cesspit. These 3 parts form the typo-morphology of the building. The basic spatial ideas of Rumah Panggong can be identified by its functionality, effectiveness, flexibility and most essentially its mother room existence.
\end{abstract}

Keywords: Local architecture; rumah panggong; architectural typo-morphology.

\section{INTRODUCTION}

The Malay tribe population in the province of Bangka and Belitung generally acknowledge Rumah Panggong Limas as the traditional home of the Malays. However, now the physical existence of Rumah Panggong Limas in Belitung Island is nowhere to be found; a model house then built by the Department of Culture and Tourism of Belitung province as an attempt of conservation. The local architectural form which is still commonly found on the Belitung Island is Rumah Panggong; the house that has the characteristics of standing on piles, a square floor plan, and a gable instead of tiered pyramid roof.

Sijuk village which is situated in Sijuk subdistrict, Belitung regency, Bangka Belitung province is geographically located in the north of Belitung Island. This village is believed to be the oldest village in Belitung Island. Society believes that one of the forerunner to the society of Belitung Island was originated from this village, because Sijuk village was the center of trade and habitation which attracted many traders from Sumatra, China, Bugis, and other areas.

In Sijuk village, the researcher found many Rumah Panggongs which are 50 or more years old, but still in a well-preserved condition. Therefore, Sijuk village was selected as the location of the study.

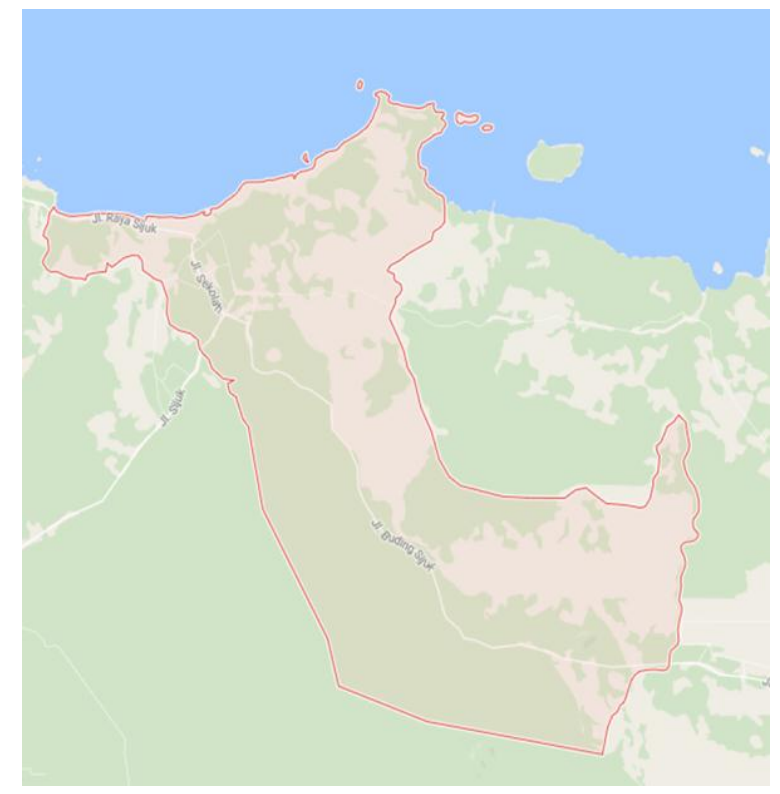

Fig. 1. Sijuk Village, Sijuk Municipality, Belitung Regency, Bangka Belitung Province (Source: Google Map, 2016).

The study is limited to the aspects of the spatial characteristics of the overall characteristics presented in the architecture of Rumah Panggong. Space aspect is chosen due to human activities inside buildings in general and residential houses in particular always get started from the space design ideas before they are then being developed into the ideas of shape, structure, construction, and so forth. 


\section{Vernacular Architecture}

Amos Rapoport (1969) mentioned that vernacular architecture has been developed from architectural understanding which is owned by local people with all kinds of tradition approaches, which also optimize or utilize the building potentials in the local area such as; materials, technology, and knowledge. Moreover, Paul Oliver (1987) in Dwellings: The House Across the World, mentioned some of the basic concepts that are owned by the vernacular architecture, namely: Rural Settlements, Types and Processes, Built from the Ground, Resources that Grow, Coping with Climate, Living Spaces, Decorated Dwellings, Values, Symbols, and Meanings.

What was described by Paul Oliver (1987) in the paragraph above was as well stated by Dell Upton in Paul Groth (1999) where vernacular building is basically a plain ordinary building. The meaning of "plain" here is a simple mindset, low cost budget, or built by traditional group which uses eternal and unchanging local culture. Thus, the vernacular architecture, which is the development of folk architecture can be seen as ecological, architectonic and natural as it refers to the conditions and climate potential, culture, society, and its environment.

\section{Malay Society in Belitung Island}

The population in Belitung Island is predominated by Malays who work as fishermen, miners, or merchants. They are widely known as Orang Melayu. When referring to the work presented by Shahminan (2015) in his article titled: "Pengaruh Sub Etnik terhadap Seni Arsitektur Warisan Melayu Johor", the Malays whose professions above-mentioned are classified as Anak Melayu Dagang, of which include the sub-tribe Melayu Banjar, Melayu Jawa and Melayu Bugis. The meaning of Anak Melayu Dagang is a sub-tribe, which was formed by the habit of fishing for trading, as well as by exploring new areas around the Malay territories which are now known as the provinces of Riau, of which situated in Indonesia. In doing daily job as a trader, it is widely common then to get settled in the new areas, in where they were looking for or selling their goods. After they got settled, they then began to interact with the local people, which then created new sub-tribes, namely Melayu Banjar, Melayu Jawa, and Melayu Bugis, who have different values from Anak Melayu Jati. The later who remained in the territory of Malay has their orginal values intact and harmonious. There was also another model of interaction, which happened between the Malay tribes and other newcomers that has coloreds or enriched their culture, but did not create new sub-tribes of Malays.

\section{Houses of Orang Melayu in Belitung Island}

Traditional houses in Belitung Island have a relationship with the house of Orang Melayu who live on the coastal area or live outside the island in various different areas within the country (Disbudpar Belitung, 2006). However, the name of each room within each inhabited house by the Malays has its own characteristic. According to a study conducted by the Department of Culture Bangka Belitung Province in 2004, the traditional houses in Bangka Belitung have similarities with the ones in the Island of Sumatra and are called Rumah Panggong. There are three types of Rumah Panggong in Bangka Belitung Province, namely 1) Rumah Panggong Limas, 2) Rumah Panggong Bubung Limas Panjang, 3) Rumah Panggong Bubung Limas. However, further explained that besides the three types of Rumah Panggong above, there are also other types of Rumah Panggong, which are simpler and developed in the coastal areas of Bangka or Belitung Island.

More detailed, the types of houses in Belitung according to the study of Department of Culture Belitung province in 2006 are namely Rumah Toko Limas, Rumah Toko Gudang, and Rumah Panggong. Rumah Toko Limas and Rumah Toko Gudang are widely available in Tanjung Pandan, Belitung Timur Regency and Seliu Island, the area which was a new area that had been opened by the Dutch government as a trade center. Rumah Toko Limas and Rumah Toko Gudang now serve as grocery stores, coffee shops, or storage rooms. While Rumah Panggong can be considered as the house of most people in Belitung Island, which is located in coastal areas or inland that serves as center of settlement or habitation (Siswanto, 1998). In general, the type of rooms within a Rumah Panggong are as follows:

1. Suyok/Terrace

A ladder-shaped room, which is the transition zone before entering the hall. There are two kinds of suyok, the first is a waist-high wooden barrier staircase with Barlian (diamond) motives. The second is also a staircase with both of its sides are limited by a cement wall.

2. Porch

The porch serves as a place to welcome guests or to perform social activities such as makan berdulang (a commensal dining) or traditional ceremonies such as wedding ceremonies and akikah (an Islamic terminology on the occasion of a child's birth). The porch can be opened or closed.

3. Mother room/Middle room

Mother room or central room is the core part of the house, where all the core activities carried out 
in this room. This room is divided into 2 parts as an open family room and bedroom with a wall or a curtain. For a special note, on the occasion of wedding ceremony the family room, either directly or with a non-permanent divider, is changed into the bridal room.

4. Cesspit

It covers the bathroom, WC, kitchen, and storage room. This room is an additional space which is not necessarily to be existed in all Rumah Panggongs. This space serves as a complement, where traditionally, people in Belitung do cooking activities in the open air, as well bathing and washing in the river.

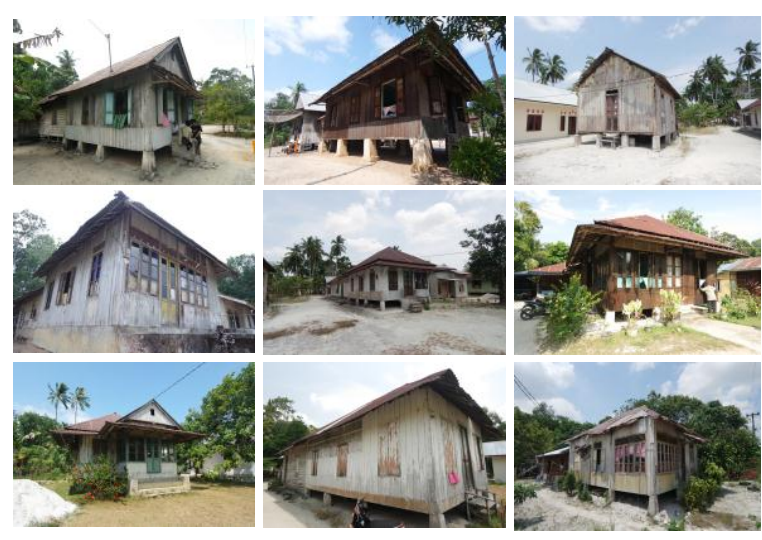

Fig. 2. Rumah Panggong in Sijuk Village

\section{RESEARCH METHODS}

The approach used in this study was qualitative descriptive. Before going to the field, the researcher built a background knowledge through primary and secondary information. The primary information was obtained through field survey of the object (measurement, protraction, and re-modelling) and by interviews of actors within the scope of research activities. While secondary information was obtained by reviewing theories on vernacular architecture and traditional ethnic Malays as well as typo-morphology. Then, after the primary data were obtained, using grounded theory, some coding techniques were applied (open coding, axial coding and selective coding) to find variations of space in Rumah Panggong. Variations were then grouped and interpreted with existing theories in order to see the characters and concept of Rumah Panggong in Sijuk district, Bangka Belitung.

\section{Data Collection Method}

In data collection, interviews and field observations were opted. The observations were made with the aim to understand the physical condition and function of Rumah Panggong in the Sijuk village, as well as to describe the floor plans, elevations, and pieces of it. Photographs to picture the atmosphere and environment of Rumah Panggong to support technical drawings of the above-mentioned architecture were also taken. After the observation was made, a structured in-depth interview with the owner or user of the building was taken. The interview aimed to explore spatial concept or basic idea of Rumah Panggong.

\section{Data Analysis Method}

The methods of data analysis used in this study were qualitative inductive analysis model. First, typomorphological architecture in spatial aspect based on the observation of Rumah Panggong in Sijuk village was being searched for. Each object was then classified based on geometric variations and as well the variations of additional functions in the building in order to find the spatial characteristics of Rumah Panggong.

In the subsequent data analysis, characteristics emerging from the similarities and variations that were shown in the rooms of Rumah Panggong were being searched for. Having opted the data encoding, this method was utilized to reduce bias in the raw data as well as to simplify categories findings that existed in the data (Corbin, 1986). The encoding process was divided into three stages, namely open coding, axial coding, and selective coding (Corbin \& Strauss, 1998).

\section{MORPHOLOGICAL AND TYPOLOGICAL ANALYSIS}

\section{Morphology of Rumah Panggong in Sijuk Village}

Rumah Panggong in Sijuk village has a very functional shape and arrangement of space, which is indicated by several things. First, the basic spatial form that is used is a square where the shortest side being the front of the building. Second, the house is presented in a very simple form where its most distinctive characteristic lies on non-tiered simple roof or known as non-saddle-shaped roof.

Rumah Panggong in Sijuk village is generally situated on a flat tread, not fenced, and orientated towards the east or the west. Due to avoiding the wind that blows from the coastal area in the north. Another reason would be the condition of the local road structure of which lies from the north to the south, therefore to get an easy access to the house the 
position of it is set to elongate to the backside, which refers to the east to west orientation. It is to maximize the lighting and air circulation within the house.

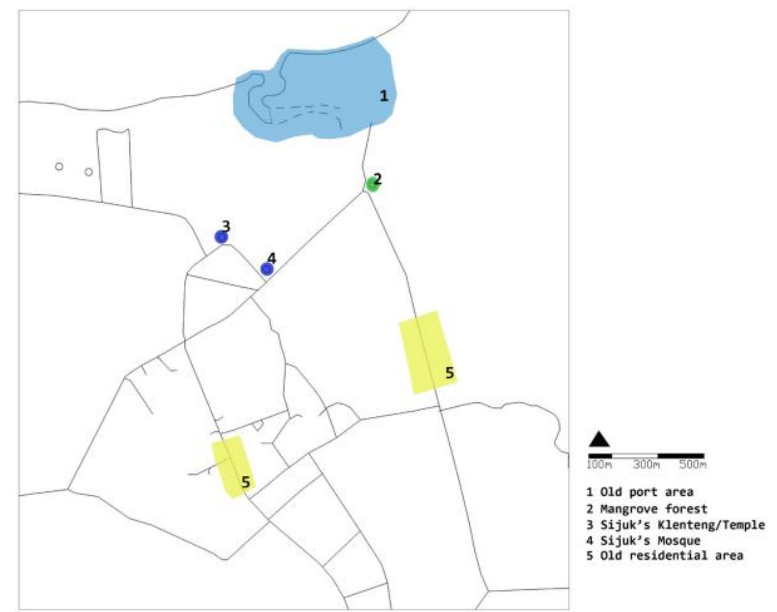

Fig. 3. Location of Rumah Panggong in Sijuk Village

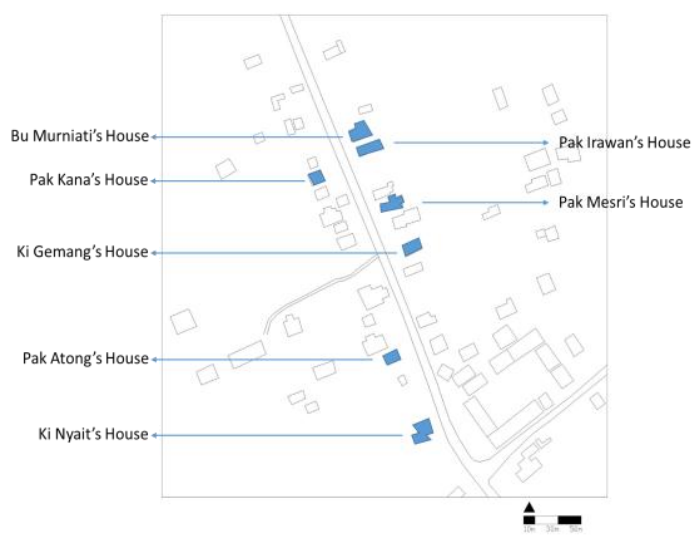

Fig. 4. Orientation of Rumah Panggong in Sijuk Village

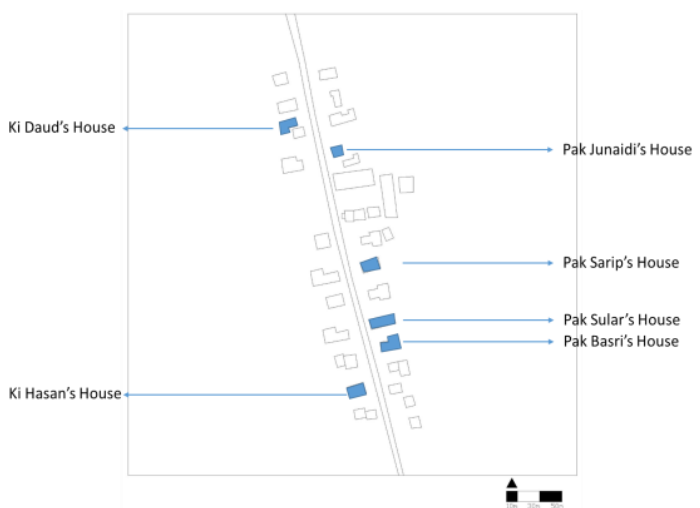

Fig. 5. Orientation of Rumah Panggong in Sijuk Village

In general, the rooms in Rumah Panggong are located under one same roof of the building. Outside the roof of Rumah Panggong, there is only a well as a source of clean water and can only be found in just a few buildings. Rooms at Rumah Panggong can be grouped into service zone and residential zone. Service zone is always separated and is in the back of the houses, located side by side with the residential zone. The two has difference in height where the service one is lower. In some cases, the service zone is not a room with stage structure but rather stick to the ground.

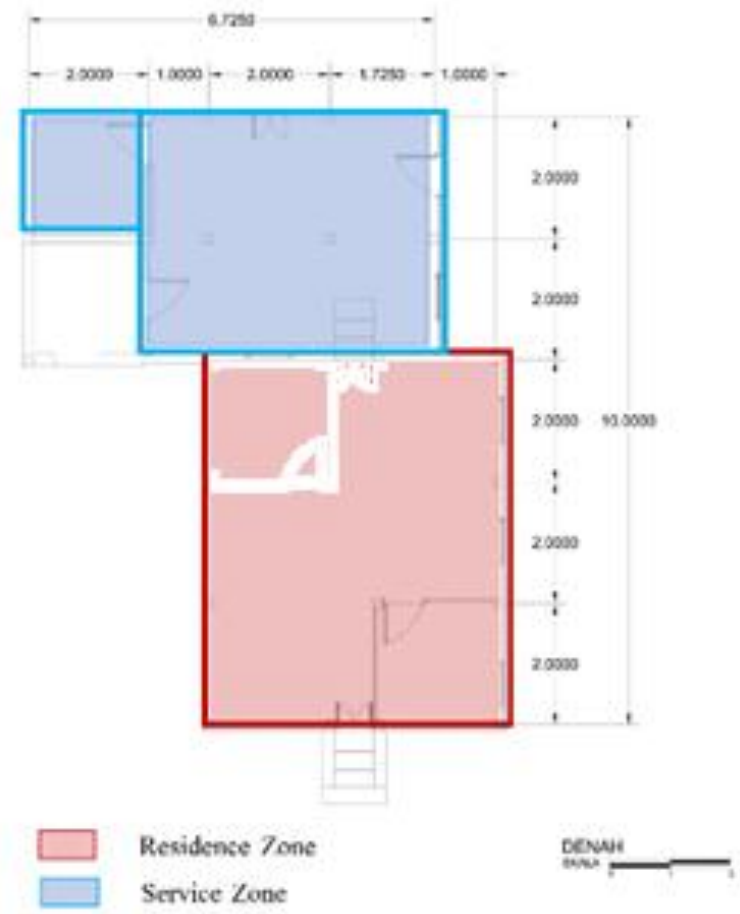

Fig. 6. Rumah Panggong Space Zone Distribution in Sijuk Village

Residential zone in the Rumah Panggong consists of mother room or living room and suyok or porch. Mother room, living room and walk-in room are intended for private household activities, while suyok or porch is allocated for semi-private household activities, i.e.: welcoming guests or holding traditional ceremonies. The mother room or the living room space with attached suyok or porch is connected with doors opening towards the inside of the building. The mother room or the hall at Rumah Panggong is often divided to living room, stall, and porch, where the relationship between them is marked by the doors that open towards the room or fabric curtain serves as a divider.

Service zones in Rumah Panggong is also known as cesspit. Within this zone, there is a division of functions, namely bathroom, WC, kitchen, and storage room. The cesspit and the living room are connected by a door opening towards the cesspit, and the cesspool and the outside area are also connected with a door located on the side of the building and opens towards it. Spaces that are below residential 
zone floor have no usage other than the circulation of air, but this space is previously used to store firewood for cooking purpose.

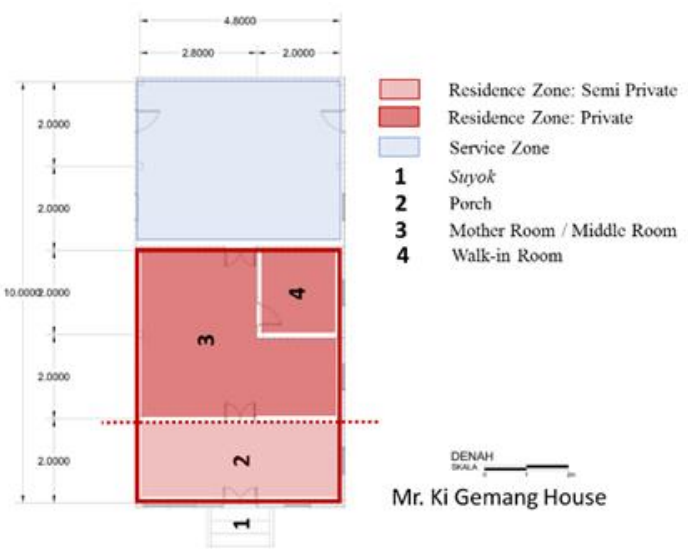

Fig. 7. Composing space in Residential Zone of Rumah Panggong

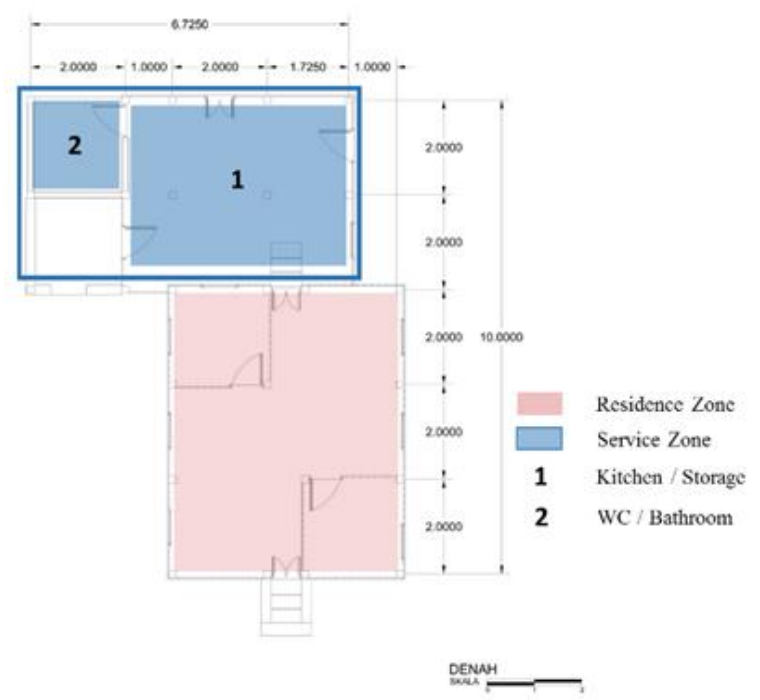

Mrs. Murniati House

Fig. 8. Composing space in Service Zone of Rumah Panggong

Access to Rumah Panggong is in the middle part of the front of the building, however, to facilitate the household activities, often an additional entrance at the service zone is created, which is located on the back of the residential zone. The additional access is located at the right side of the building, when it is viewed from the front of Rumah Panggong and oriented from the east to the west.

\section{Typology of Rumah Panggong in Sijuk Village}

Based on the discussion above, the space typology of Rumah Panggong in the Sijuk village can be divided into three based on the completeness of space. They are:

1. Small Type

This type of Rumah Panggong consists of one part only, which is the mother room or the living room and stall. Where all household activities take place in this room. Supporting activities such as washing and bathing are done outside the house, such as in the river.

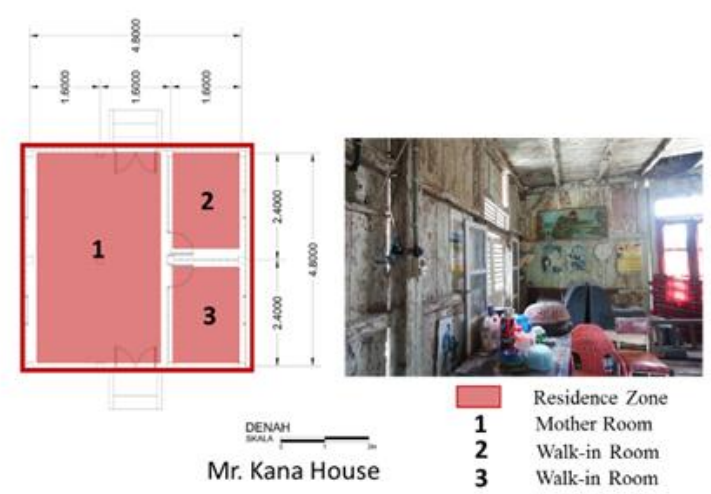

Fig. 9. Rumah Panggong Small Type

2. Medium Type

This type of Rumah Panggong consists of two parts, namely the mother room or the living room and a stall with attached suyok or porch in the front section. This type of house already has the capacity to hold some custom events like makan bedulang, akikah, and tahlilan, except wedding ceremony. Just like in the small type, supporting activities such as washing and bathing can be done outside the house, such as in the river.

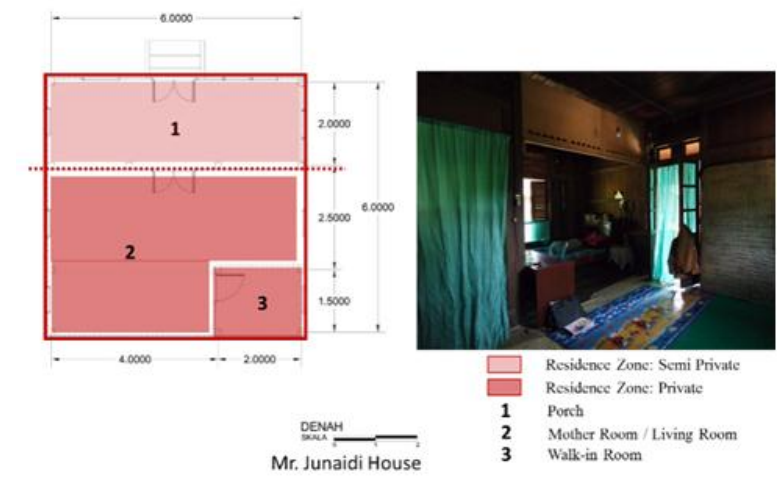

Fig. 10. Rumah Panggong Medium Type

\section{Large Type}

This type of Rumah Panggong consists of three parts, namely the mother room or the hall and a stall, attached suyok or porch on the front and cesspit on the back. This type of house has the capacity for all ceremonies to take place, including wedding ceremony. Other supporting activities such as washing and bathing are no longer done 
outside the house or in the river, but instead in the cesspit.
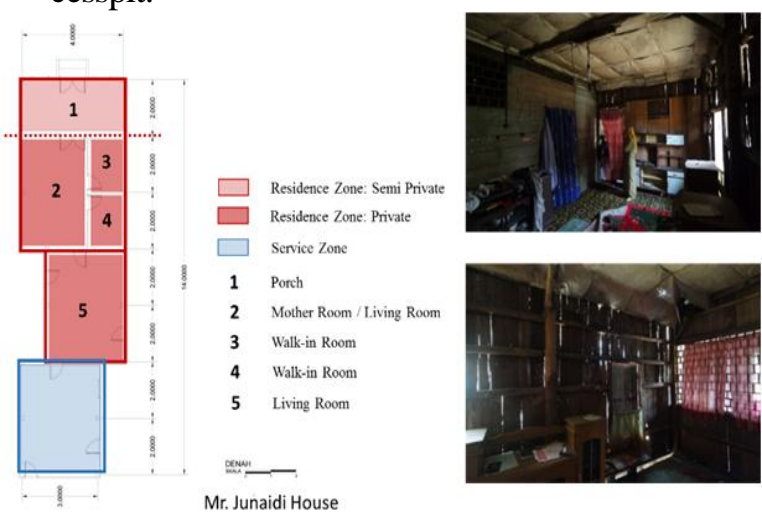

Mr. Junaidi House

Fig. 11. Rumah Panggong Large Type

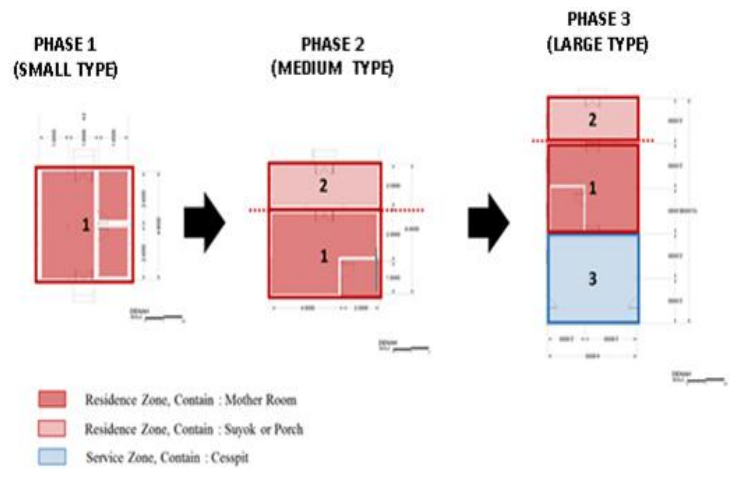

Fig. 12. Transformation Phase of Rumah Panggong

\section{Space Creating Concept of Rumah Panggong in Sijuk Village}

Mother room or living room is the core room in Rumah Panggong. There are two reasons, the first is because in this room, most of the household activities take place, such as eating, and hanging out with family, and the second is from this mother room, then the other rooms are formed. For Orang Melayus, whose incomes are limited, their Rumah Panggong consists of only one room, which is the mother room; it is established in the form of open-plan space that can be used for various types of activities. However, after they have enough income, they usually then create dividers to the mother room or add other rooms that are attached to it. Once the mother room is divided, the naming of the room is shifted to be the living room.

There is a pattern or trend in this division or additions to the mother room. The first stage is to divide the mother room with permanent dividers made of wooden planks, with the length following to the length of the building, then the east part of the building is generally used as a stall, and the west part is used as a living room which doubled as a porch.
The number of stalls is tailored to the needs of the homeowner or family members, however, two is the most commonly number we can find, of which one booth belongs to the parents, and the other to the daughters. The sons in the family sleep in the living room, hence they do not have bedroom on their own and therefore a stall is not needed to be built. At this stage, the mother room has been then transformed into a living room and a stall.

Next, the second phase is the addition of suyok in the form of open patio or porch that has more enclosed space. However, although the porch is a more common option compared to suyok, in some cases both can be found in the house. The way to bring suyok or porch to Rumah Panggong is by dividing the space at the front of the building or adding a new room attached to the mother room. The dimension of suyok or porch of Rumah Panggong is adjusted to the width of the front of the building, where it will be the the length of suyok or the porch and the length of the backside of the stall will be the width. In the case of buildings with both suyok and porch, porch's dimension is generally adjusted to the length and width of the stall, and suyok's dimension is adjusted to the length and width of the living room. The use of suyok or porch is to facilitate the social function. Social function means welcoming guests or hosting cultural traditions such as makan bedulang, akikah, or tahlilan. While in a wedding ceremony, suyok or porch is used to welcome guests, and the living room is used as a bridal room.

The next stage of the development of space in Rumah Panggong is the addition of cesspit to facilitate the supporting functions of Rumah Panggong. Cesspit consists of a large room that is used for cooking, washing, bathing and storing. There is no divider in this cesspit, except for the shower, which shares space with the toilet. With the large space available, it serves the homeowners a more flexible and effective opportunity to host visiting neighbors in helping them in cooking activity. In some cases, cesspit is often bigger than mother room which is situated in front of it. It is intended to make the entrance door to the cesspit directly from the outside of the building presentable and to make it having the opening direction similar with where the main door has.

\section{CONCLUSION}

Rumah Panggong building as a local architectural showcase of Malay community basically focuses on aspects of functionality which can accommodate the household activities in its spaces. It is shown in the 
simplicity of the form of the existing space in Rumah Panggong, where the rooms are shaped to be geometrical square and positioned from the front to the back, as well as from the flexibility of the use of space, which is visible from the minimum use of room dividers.

In addition, Rumah Panggong also has a strict zoning division between private and semi-private zones, and between clean and dirty zones. It can be seen from the use of permanent dividers, which are only intended to divide parts of the house into 3 sections namely mother room, suyok or porch, and cesspit.

Rumah Panggong has a concept of growing house where the physical form and size of the house can be developed and expanded in line with the financial ability of homeowners. Mother room has an important role in the Rumah Panggong, as it serves as the core room and the initial point of the development and the expansion of the house.

Based on the discussion above, the form of Rumah Panggong is indeed adapted to the characteristics of Malay society in Belitung Island, of which is predominated by the Anak Melayu Dagang tribe whom prefer the practical and efficient aspects better in their process of building a house. This category of Malay society mainly lives in the coastal areas of Sumatra or in the small islands in the periphery of the Sumatra Island.

\section{REFERENCES}

Corbin, J. (1986). Coding, Writing Memos, and Diagramming. In Chenitz, C.W. \& Swanson, J.M. From Practice to Grounded Theory: Qualitative Research In Nursing. Addison-Wesley Publishing Company, Menlo Park, CA.

Dinas Kebudayaan Kabupaten Belitung. (2006). Laporan Sarasehan Desain Rumah Adat Belitong. 5-6 Oktober, Tanjung Pandan.

Oliver, P. (1987) Dwellings: The House Across the World. Phaidon, Oxford.

Roesmanto, T. (2013). Ke-Arsitektur Melayu-an Berbalut Kesejarahan Yang Terlupakan, Proceeding Seminar Nasional Arsitektur Melayu. Sebuah Peneguhan Ke-Identitas-an Arsitektur, IAI Daerah Kepri. Batam.

Rapoport, A. (1969). House Form and Culture. Prentice Hall, Englewood Cliffs NJ.

Siswanto (1998), Inventaris Kebudayaan di Pulau Bangka dan Belitung, Dinas Pendidikan dan Kebudayaan Provinsi Sumatera Selatan. Indonesia.

Supriyanto (2015). Rekam Jejak Arsitektur Melayu. IAI Daerah Kepri, Riau.

Strauss, A. L. \& Corbin, J. M. (1998). Basics of Qualitative Research: Techniques and Procedures for Developing Grounded Theory, SAGE Publications, Inc, California. 